\title{
Tourism Development from the Perspectives of Sustainability in Melaka State
}

\author{
A. S. A. Ferdous Alam ${ }^{1}$, Er A. C. ${ }^{2}$, Halima Begum ${ }^{3}$ \\ ${ }^{1}$ Institute for Environment and Development (LESTARI), Universiti Kebangsaan Malaysia (UKM), \\ 43600 UKM Bangi, Selangor, Malaysia \\ ${ }^{2,3}$ Faculty of Social Sciences and Humanities (FSSK), Universiti Kebangsaan Malaysia (UKM), 43600 \\ UKM Bangi, Selangor, Malaysia
}

\begin{abstract}
Tourism is an important development tool and it is considered the second largest contributor to the Malaysian economy. Even though the visitors are satisfied by the prevailing facilities, a few shortcomings need to be addressed on sustainable tourism such as the lack of knowledge on sustainable tourism in different sectors, and the neglected local communities in making decisions on sustainability. The aim of this study is to realize the relationship between three factors namely economy, environmental impacts of tourism, and community satisfaction and perceptions on tourism development in Melaka, a UNESCO World Heritage site in Malaysia. In order to observe this relationship, 735 tourists were interviewed to get the tourists' responses. Here, the concepts on sustainable tourism development include the conservation of the environment, mitigation of pollution from tourism development, and support of local economies. Additionally, sustainable tourism is aimed at generating local employment for the community. Data from the interviews have been analysed using descriptive and simple statistical tools. It is found that the variables are suitable in this study due to the high Cronbach's Alpha values. The study found that there are positive significant influences between the three dimensions and their perceptions on sustainability and tourism development.
\end{abstract}

\section{Introduction}

In modern economy, tourism is the most significant leading source in the world. It has been declared as one of the main noteworthy service industries globally [1]. The definition of tourism includes "travelling to relatively continuous or uncontaminated natural areas with a focus on knowledge, appreciating and enjoying the scenery and its wild flora and fauna, and other prevailing cultural and historical aspects", as it consists of places of historical importance, archaeological and religious sites, sanctuaries, parks, hill resorts, clubs, beaches, etc. It is a multi-sector industry including a collection of industries, activities, and services that deliver travel experiences such as transportation, accommodation, eating and drinking businesses, retail shops, entertainment businesses, activities, facilities, and other hospitality services offered for individuals or groups travelling away from home [2].

The World Trade Organization [3] forecasted that by the year 2010, this sector would expand by an average of $4.1 \%$ a year over the next two decades, exceeding 1 billion total worldwide travelers and reaching 1.6 billion by 2020 . In addition, socially, environmentally, and economically, sustainable tourism is really a crucial matter in numerous government agendas. 
In the tourism industry, achieving competitive advantage refers to the notion where a destination must have an overall "appeal" and where the tourist experience offered is superior to that of alternative destinations competing for the same target tourists [4]. This study, therefore, is an attempt to understand the factors that attract tourists to visit Malaysia and consider it as a tourist destination.

\section{Literature Review}

The report of [5] mentioned that the innermost hypothesis of sustainable development (SD) is "that which meets the needs of the present without compromising the ability of future age groups to meet their own needs". As a development approach, this sector has achieved significant earnings and has provided substantial contribution to the local and national economy in many countries. It is also identified as one of the largest and fastest growing industries [6, 7, 8]. For some developed or developing countries, the tourism industry forms a critical component of the local, regional and national economy, contributing significantly to employment opportunities, GDP growth, and foreign exchange earnings. Tourism has turned out to be one of the very important sources of earnings for developed countries as well where it has already created a substantial foundation for a tourism based economy, for example in countries like Singapore, Maldives and Malaysia in which the total contribution of the Travel \& Tourism sector to the GDP in 2011 was $8.2 \%, 70.5 \%, 15 \%$, respectively.

Today, the tourism industry of Malaysia has moved with such rapidity to become the second income generator in the national economy whilst experiencing tremendous growth year by year. The total contribution of travel and tourism to the GDP was $15.8 \%$ in 2013 [9]. Even though the tourism industry is a latecomer in Malaysia compared to its neighbouring countries, namely Thailand and Singapore, it has recorded successful performance in terms of tourist arrivals and receipts [10]. For example, in 2010, Malaysia recorded 24.5 million tourist arrivals and RM55.6 billion in tourist receipts compared to 5.5 million tourist arrivals and RM8.5 billion in tourist receipts in 1998 [11]. Globally, Malaysia was ranked 9th in the top ten most visited countries in terms of international tourist arrivals in 2009 and 2010, achieving figures of 23.6 and 24.6 million tourist arrivals, respectively $[12,13]$.

Malaysia can make an exceptional contribution to the tourism sector by attracting various researchers and academicians globally for support in this study. The government has declared sustainable tourism as an instrument of development giving precedence with least negative impacts to defend the environment and traditions [14]. In addition, it is generally used for increasing the economic growth of a country and tourism development should be encouraged [15].

Lying just north of the equator, Malaysia is located south of Cambodia and Vietnam and north of Singapore and Indonesia. More than one thousand islands are part of Malaysia with 38 designated as marine parks. Parts of the primeval rainforest are more than 100 million years old with a dazzling selection of birds and wildlife. Malaysia has wonderful golden beaches, lush vegetation, mountains, and fabulous shopping centres, which are associated with some magnificent hotels. This has made the country the fastest growing destination in South East Asia. The mix of the ancient and the ultramodern makes Malaysia a fascinating place to visit, while the low cost of living and huge selection of choices for visitors make it an ideal holiday location. Malaysia experiences tropical climate throughout the year, enjoying warm days and mild evenings in all seasons. The country also offers a fascinating cultural mix with colourful festivals, unique arts and crafts, architecture, food and a rich array of dance forms. It is ideally placed to take advantage of its increased interest in the tourism industry, especially the ecotourism segment, as it possesses a wide variety of natural land and marine habitats. Therefore, the long term prospects of Malaysian tourism remain optimistic as a result of a strong government support and a relatively strong and stable political situation [16].

Admittedly, according to [17], foreign tourist arrivals and tourist expenditure on the basis of per capita and per diem are increasing year by year in Malaysia. Malaysia has targeted to capture a place within the top 10 countries in the world in terms of international tourist arrivals through various development plans. In this regard, less developed countries (LDCs) consider tourism as an important tool for their economic development [18]. 


\section{Data and Method}

This study collected primary data via interviews among 735 tourists based on a survey questionnaire and it was carried out between October and November, 2013. The non-probability convenience sampling technique was used for collecting data. Melaka was preferred as the research area because as mentioned by [19], "it has been chosen by tourists as a family holiday destination because there are a lot of national heritage and historical sites in the state". Heritage buildings such as the A-Famosa, Stadhuys, and traditional shop houses in the city are still protected by maintaining its aesthetic value. Similarly, the Kampung Morten culture is demonstrated through dance and traditional music as well as arts, batik, and puppet shows to attract tourists.

The data collection method used a questionnaire with a five-point Likert scale such as agree and disagree, etc. because it is a useful technique in a survey-based research; respondents choose one option that best aligns with their view. Therefore, the Likert-type rating scale has had great popularity among social science researchers [20,21].

\section{Conceptual Framework}

Mainly, there are three pillars of sustainability namely environment, economic and community. These are shown below:

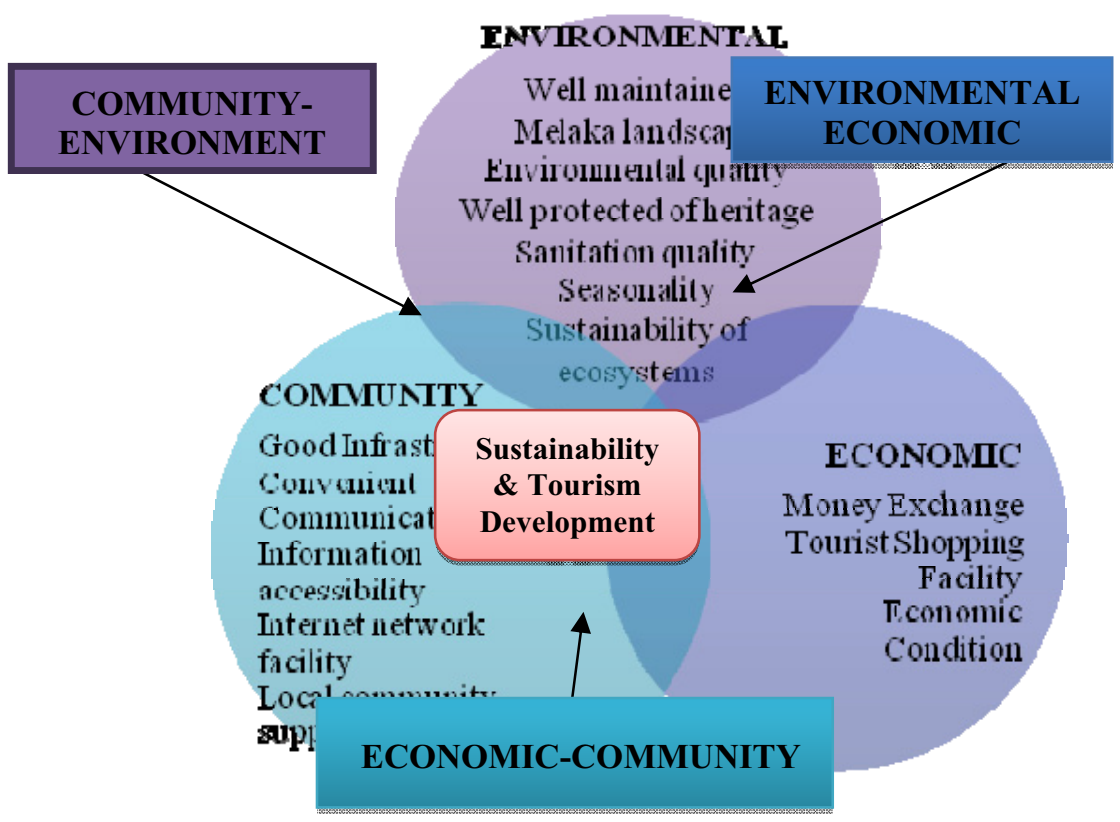

Figure 1. Conceptual Framework

Source: Adopted from sustainability assessment and reporting for the University of Michigan 200

\section{Demographic profile of survey respondents}

Table 1 illustrates that there are no differences in terms of gender and marital status among the respondents. In terms of age range, most of the respondents are categorized within the 21 to 30 years age group whereas the following group is the 31 to 40 years age group. Most of the visitors are also 
from the Malay ethnic group and the religion of most respondents is Islam. The majority of the respondents are self-employed, at almost $35.24 \%$. Around $75 \%$ of the tourists are Malaysians; most of them are from Melaka at $17 \%$ while others are from Selangor (12.38\%), Kuala Lumpur (10.48\%), Johor Baru (8.57\%), Negeri Sembilan (4.22\%), Kelantan (4.22\%), Kedah (3.53\%), Pulau Pinang (3.4\%), Perak (2.86\%), Sabah (2.58\%), Terengganu (2.04\%), Pahang (1.49\%), Sarawak (1.22\%), Perlis $(0.68 \%)$ and others $(7.76 \%)$.

About $62 \%$ of them have higher degrees, as they reported being a diploma holder or a graduate. Around $28 \%$ of the families consist of 5-6 people while $33.47 \%$ of the families comprise of 3-4 members. Most of the respondents' incomes are below RM 1000 (about USD \$300). 50\% of the respondents stay for at least one night while visiting Melaka.

Table 1. Demographic profile of the Tourists'

\begin{tabular}{|c|c|c|c|c|c|}
\hline Issues & 1 & 2 & 3 & 4 & 5 \\
\hline $\begin{array}{l}\text { Respondent's } \\
\text { gender }\end{array}$ & Male (51.16) & Female (48.84) & & & \\
\hline $\begin{array}{l}\text { Respondent's } \\
\text { age }\end{array}$ & $11-20(13.33)$ & $21-30(40.54)$ & $31-40(26.67)$ & $41-50(12.65)$ & $50-<(6.81)$ \\
\hline Ethnic & Malay (58.64) & Indian (7.21) & Chinese (14.69) & Others (19.46) & \\
\hline Religion & Islam (64.9) & Hindu (7.21) & Buddha (10.61) & $\begin{array}{l}\text { Christian } \\
(14.42)\end{array}$ & $\begin{array}{l}\text { Others } \\
(2.86)\end{array}$ \\
\hline $\begin{array}{l}\text { Marital } \\
\text { Status }\end{array}$ & Married (48.16) & Single (48.16) & $\begin{array}{l}\text { Single Mothers } \\
(2.45)\end{array}$ & $\begin{array}{l}\text { Single Fathers } \\
(0.68)\end{array}$ & $\begin{array}{l}\text { Others } \\
(0.55)\end{array}$ \\
\hline Profession & $\begin{array}{l}\text { Self Employed } \\
(35.24)\end{array}$ & $\begin{array}{l}\text { Government } \\
(25.85)\end{array}$ & Private (26.94) & Others (11.97) & \\
\hline $\begin{array}{l}\text { Income } \mathrm{P} / \mathrm{M} \\
(\mathrm{RM})\end{array}$ & $\begin{array}{l}\text { Below } 1000 \\
(42.04)\end{array}$ & $\begin{array}{l}1001-1500 \\
(8.57)\end{array}$ & $\begin{array}{l}1501-2000 \\
(14.42)\end{array}$ & $\begin{array}{l}2001-2500 \\
(6.8)\end{array}$ & $\begin{array}{l}2501< \\
(28.16)\end{array}$ \\
\hline $\begin{array}{l}\text { Level of } \\
\text { Education }\end{array}$ & $\begin{array}{l}\text { Diploma/Degree } \\
(61.91)\end{array}$ & $\begin{array}{l}\text { Primary school } \\
(14.15)\end{array}$ & $\begin{array}{l}\text { High school } \\
(20.68)\end{array}$ & $\begin{array}{l}\text { Not in school } \\
(1.22)\end{array}$ & $\begin{array}{l}\text { Others } \\
(2.04)\end{array}$ \\
\hline $\begin{array}{l}\text { Respondents' } \\
\text { nationality }\end{array}$ & $\begin{array}{l}\text { International } \\
(17.41)\end{array}$ & $\begin{array}{l}\text { Malaysian } \\
(74.83)\end{array}$ & Others (7.78) & & \\
\hline $\begin{array}{l}\text { No of } \\
\text { Households }\end{array}$ & Below $2(24.22)$ & 3-4 (33.47) & $5-6(27.76)$ & $7(8.44)$ & $8-<(6.11)$ \\
\hline $\begin{array}{l}\text { Category of } \\
\text { visits }\end{array}$ & Local (19.32) & Visitors (29.93) & $\begin{array}{l}\text { Tourist* } \\
(50.48)\end{array}$ & Others $(0.27)$ & \\
\hline
\end{tabular}

Source: Authors' analysis on primary survey from Melaka 2013

Note: * Who stayed at least 1 night treated as tourist and rest are visitors;

Percentage in the parenthesis

\section{Result and analysis}

Tourism planning and development in terms of sustainability has become an important concept and topic [22- 24 ]. This focus is in part due to tourism's inherent nature to have both positive and negative effects on an economy, environment, and the community. [25-27] indicated that, "if tourism development was planned improperly, it could destroy the very resources that are the foundation of tourism in a community (e.g. economic, environmental and social)".

\subsection{Reliability and convergent validity}

Cronbach's alpha was used to determine the reliabilities of the multi-item factors. The reliability level for attitude in the direction of economy, environment, and community met the critical value of 0.7 as suggested by [28]. All of the variables have high Cronbach's Alpha values such as $0.795,0.886$, and 
0.872 for economy, environment and community, respectively. This proves that the variables are significant and suitable as all the variables used have higher than the suggested value.

\subsection{Economic factors}

The availability of adequate money exchange facilities is an important economic factor that allures tourists to visit Melaka as mentioned by $68.57 \%$ of the respondents (Table 2). This is followed by the attractive facilities for shopping and availability of gift and souvenir shops, which have attracted tourists to come to this place as mentioned by $67.62 \%$ of the respondents. Three main economic features that are important in developing countries for sustainable tourism are income generation, employment opportunity, and foreign exchange earnings. For instance, for many third world countries, tourism is the major income source of foreign exchange. Less developed countries (LDCs) have considered sustainable tourism as a vital tool for their economic growth [29] and tourism earnings reduce levels of reliance on exports of traditional primary commodities, providing an opportunity for many developing countries to diversify their economic bases [30,31,32]. Overall, the economic condition and its growing nature were mentioned by $68.03 \%$ of the respondents as another factor that attracts tourists to Melaka.

Table 2. Economic factors of tourism development for Sustainability in Melaka

\begin{tabular}{llllllll}
\hline Economic Issues & $\mathbf{1}$ & $\mathbf{2}$ & $\mathbf{3}$ & $\mathbf{4}$ & $\mathbf{5}$ & $\begin{array}{l}\text { Mean } \\
(\mathbf{\% )})\end{array}$ & SD (\%) \\
\hline Money exchange & 2 & 24 & 205 & 344 & 160 & & \\
& $(0.27 \%)$ & $(3.27 \%)$ & $(27.89 \%)$ & $(46.80 \%)$ & $(21.77 \%)$ & 3.87 & 0.8 \\
Tourist shopping & 3 & 32 & 203 & 331 & 166 & & \\
$\begin{array}{l}\text { Overall Financial } \\
\text { conditions of the }\end{array}$ & $(0.41 \%)$ & $(4.35 \%)$ & $(27.62 \%)$ & $(45.03 \%)$ & $(22.59 \%)$ & 3.85 & 0.83 \\
locality & $(1.09 \%)$ & $(1.90 \%)$ & $(28.98 \%)$ & $(46.94 \%)$ & $(21.09 \%)$ & 3.85 & 0.81 \\
\hline
\end{tabular}

Source: Authors' analysis on primary survey from Melaka 2013

Note: $1=$ Very Unsatisfied; $2=$ Unsatisfied; $3=$ Neutral, $4=$ Satisfied; $5=$ Very Satisfied, Percentage in the parenthesis

\subsection{Environmental factors}

About $72.38 \%$ of the respondents were satisfied and very satisfied with the well-maintained heritage sites in Melaka (Table 3). Moreover, around $65.71 \%$ of the respondents agreed that they were satisfied with the quality of sanitation and hygiene facilities as the facilities are available and conveniently located around the city. Melaka's beauty in terms of landscape and the well-protected ecological heritage site were selected by $70.75 \%$ and $70.88 \%$ of the respondents, respectively. The eco-friendly environment and the good practices in the sustainability of the eco-system have contributed to visitors being attracted to visit Melaka as mentioned by $69.66 \%$ and $70.2 \%$ of the respondents, respectively. However, most of the visitors, namely around $63.95 \%$, reported that they came based on the seasonality of the weather. For example, sustainability has become an important topic and concept in relation to tourism planning and development [33]. To support this, the World Wide Fund for Nature [34] indicated that sustainable tourism is like a fire; you can cook your dinner on it, but if you are not careful, it will burn your house down. However, this focus is in part due to tourism's inherent nature to have both positive and negative effects on the environment. 
Table 3. Environment factors of tourism development for Sustainability in Melaka

\begin{tabular}{|c|c|c|c|c|c|c|c|}
\hline $\begin{array}{l}\text { Environmental } \\
\text { Issues }\end{array}$ & 1 & 2 & 3 & 4 & 5 & $\begin{array}{l}\text { Mean } \\
(\%)\end{array}$ & SD (\%) \\
\hline Well maintained & $2(0.27 \%)$ & $\begin{array}{l}19 \\
(2.59 \%) \\
20\end{array}$ & $\begin{array}{l}182 \\
(24.76 \%) \\
193\end{array}$ & $\begin{array}{l}388 \\
(52.79 \%) \\
344\end{array}$ & $\begin{array}{l}144 \\
(19.59 \%) \\
176\end{array}$ & 3.88 & 0.75 \\
\hline Melaka landscape & $2(0.27 \%)$ & $(2.72 \%)$ & $(26.26 \%)$ & $(46.80 \%)$ & $(23.95 \%)$ & 3.91 & 0.79 \\
\hline $\begin{array}{l}\text { Environmental } \\
\text { quality }\end{array}$ & $4(0.54 \%)$ & $\begin{array}{l}24 \\
(3.27 \%)\end{array}$ & $\begin{array}{l}195 \\
(26.53 \%)\end{array}$ & $\begin{array}{l}372 \\
(50.61 \%)\end{array}$ & $\begin{array}{l}140 \\
(19.05 \%)\end{array}$ & 3.87 & 0.78 \\
\hline $\begin{array}{l}\text { Well protected of } \\
\text { heritage }\end{array}$ & $2(0.27 \%)$ & 23 & 189 & 360 & $\begin{array}{l}161 \\
(21.90 \%)\end{array}$ & 3.89 & 0.78 \\
\hline Sanitation quality & $4(0.54 \%)$ & $\begin{array}{l}34 \\
(4.63 \%) \\
23\end{array}$ & $\begin{array}{l}214 \\
(29.12 \%) \\
240\end{array}$ & $\begin{array}{l}336 \\
(45.71 \%) \\
335\end{array}$ & $\begin{array}{l}147 \\
(20 \%) \\
135\end{array}$ & 3.82 & 0.8 \\
\hline $\begin{array}{l}\text { Seasonality } \\
\text { Sustainability of } \\
\text { ecosystems }\end{array}$ & $2(0.27 \%)$ & $\begin{array}{l}(3.13 \%) \\
22 \\
(2.99 \%)\end{array}$ & $\begin{array}{l}(32.65 \%) \\
193 \\
(26.26 \%)\end{array}$ & $\begin{array}{l}(45.58 \%) \\
339 \\
(46.12 \%)\end{array}$ & $\begin{array}{l}(18.37 \%) \\
177 \\
(24.08 \%) \\
\end{array}$ & 3.79 & $\begin{array}{l}0.78 \\
0.81 \\
\end{array}$ \\
\hline
\end{tabular}

Source: Authors' analysis on primary survey from Melaka 2013

Note: $1=$ Very Unsatisfied; $2=$ Unsatisfied; $3=$ Neutral, $4=$ Satisfied; $5=$ Very Satisfied, Percentage in the parenthesis

\subsection{Community factors}

All kinds of infrastructural facilities in Melaka are satisfactory as mentioned by around $69.53 \%$ of the respondents (Table 4). Around $58.78 \%$ of the respondents mentioned that the internet access facility is good. Information from the local people is also easily accessible at the same time, as mentioned by $60.28 \%$ of the respondents. Though sustainable tourism has been perceived as the industry of the future, it faces many challenges as it enters the new century. These challenges include a greater commitment by the communities that serve as hosts to the tourists with increased respect for the places $[35,36,37]$, and a greater responsibility towards the tourists themselves $[38,39]$. However, the ultimate challenge is in delivering tourism products that are appropriate and compatible with both hosts and guests. The community is also very supportive locally and this was mentioned by $64.08 \%$ of the respondents. Lastly, the convenience of the overall communication in Melaka has attracted tourists to visit Melaka, as mentioned by $62.31 \%$ of the respondents.

Table 4. Community factors of tourism development of sustainability in Melaka

\begin{tabular}{llllllll}
\hline $\begin{array}{l}\text { Community } \\
\text { Issues }\end{array}$ & $\mathbf{1}$ & $\mathbf{2}$ & $\mathbf{3}$ & $\mathbf{4}$ & $\mathbf{5}$ & $\begin{array}{l}\text { Mean } \\
(\%)\end{array}$ & $\begin{array}{l}\text { SD } \\
\text { (\%) }\end{array}$ \\
\hline $\begin{array}{l}\text { Good } \\
\text { Infrastructure }\end{array}$ & $1(0.14 \%)$ & $\begin{array}{l}(2.31 \%) \\
\text { Convenient }\end{array}$ & $\begin{array}{l}(206 \\
(28.03 \%)\end{array}$ & $\begin{array}{l}376 \\
(51.16 \%)\end{array}$ & $\begin{array}{l}135 \\
(18.37 \%)\end{array}$ & 3.85 & 0.74 \\
$\begin{array}{l}\text { Communication } \\
\text { Information easily }\end{array}$ & $3(0.41 \%)$ & $(4.63 \%)$ & $(32.65 \%)$ & $(46.80 \%)$ & $(15.51 \%)$ & 3.72 & 0.79 \\
accessible & $5(0.68 \%)$ & $(5.31 \%)$ & $(33.74 \%)$ & $(45.99 \%)$ & $(14.29 \%)$ & 3.68 & 0.81 \\
Internet network & 10 & 50 & 243 & 322 & 110 & & \\
facility & $(1.36 \%)$ & $(6.80 \%)$ & $(33.06 \%)$ & $(43.81 \%)$ & $(14.97 \%)$ & 3.64 & 0.86 \\
$\begin{array}{l}\text { Local community } \\
\text { supports }\end{array}$ & & 31 & 226 & 355 & 116 & & \\
\hline
\end{tabular}

Source: Authors' analysis on primary survey from Melaka 2013

Note: $1=$ Very Unsatisfied; $2=$ Unsatisfied; $3=$ Neutral, $4=$ Satisfied; $5=$ Very Satisfied, Percentage in the parenthesis 


\section{Conclusion}

Sustainable tourism is a development strategy that has already become noticeable as a dominant source of income and employment generation, and a global economic contributor to GDP in many countries. Tourism generates employment, attracts foreign investment, and represents a key source of earnings for developing countries that have an inadequate industrial sector and depend on foreign aid to a great extent. The overall picture of Malaysia as a tourist destination is positive and the findings of the study indicate that the tourists were satisfied with their visits given the sustainable tourism preservation in the city in Melaka.

Cooper et. al. [40] indicated that, "If sustainable tourism is dominated by the public sector, it is unlikely to be developed at the most advantageous proportion". Thus, the private sector can play a crucial role in managing tourism and its objectives. Profit as well as business survival in the long term depends on maintaining attractive facilities in tourism destinations whereas the role of customers (tourists) must not be ignored. Malaysia is perceived by international tourists as offering natural attractive beauty, especially its historical places, unique tourist attraction points, beaches, and good facilities such as providing quality restaurants and hotels. It was found that the overall economic issues are increased tourist activities such as increased tourist shopping which in turn increases money exchange.

The job opportunity in Melaka has increased as well in order to offer various tourist support services and the overall income from tourism has also increased. Additionally, Melaka is also perceived to be offering adequate facilities in meeting the tourists' needs for food and accommodation; tourist sites are well maintained, landscapes are nice, the community is friendly and the environment is well protected. Furthermore, the sound infrastructure, convenient communication, and adequate internet facilities are important catalysts for sustainable tourism in Melaka.

\section{Acknowledgements}

This work was supported by the Fundamental Research Grant under FRGS/1/2013/SS08/UKM/02/1 headed by Associate Prof. Dr. Er Ah Choy, Faculty of Social Sciences and Humanities (FSSK), Universiti Kebangsaan Malaysia (UKM) and Grant number DPP-2014-105 led by Prof. Joy Jacqueline Pereira, Southeast Asia Disaster Prevention Research Institute (SEADPRI), Universiti Kebangsaan Malaysia (UKM) are gratefully acknowledged.

\section{References}

1. H.J. Schumacher. Ecotourism. Business World, S1/6 (2007)

2. Bhargava Mohit. Raj Pub (2009)

3. World Tourism Organization Madrid: WTO (1999)

4. L. Dwyer and C. Kim. Determinants and Indicators. Current Issues in Tourism, 6, 5, 369-414 (2003)

5. G. Brundtland G, OUP (1987)

6. M.L.Miller. Proceedings of the 1990 Congress on Coastal and Marine Tourism Newport, OR: National Coastal Resources Research and Development Institute Vol. 1 , 1-8 (1990)

7. C. Hunter. JST 3 (3), 155-65 (1995)

8. S. McMinn. The Environmentalist 2, (1997) 135-141 (1997)

9. World Travel and Tourism Council, (2013)

10. Tourism Malaysia Tourism today. Ministry of Tourism (2011)

11. Mintel Country report no.2, Mintel International Group Ltd. (2011)

12. United Nations Study on the role of tourism in socio-economic development (2007)

13. World Tourism Organization UNWTO, Tourism Highlights (2011) 
14. A. Liu, \& G. Wall. Planning Tourism Employment: A Developing Country Perspective. Tourism Mgt, 27, 1,159-170 (2006)

15. C.M. Hall . Longman (1995)

16. Malaysia Tourism Report Business Monitor International, 5 (2010)

17. M.A.H. Bhuiyan, C. Siwar, S.M. Ismail, S. M., ASS, 9, (2013)

18. M. Taleghani. J Amer Sci, 6(11) 412-416 (2010)

19. A.C. Er. Geografia: Malaysian JSS 9, 3, 12-23 (2013)

20. R. Likert, S. Roslow \& G. Murphy. JSP, 5, 228-238 (1934)

21. C-N. Wang, \& L. Weng. Chinese Jour of Psy 44, 239-251 (2002)

22. E. Inskeep, Van Nostrand Reinhold (1991)

23. C. Southgate \& R. Sharpley. Tourism and Development: Concepts and issues, Channel View. (2002)

24. F. Yuksel, B. Bramwell and A. Yuksel. Tourism Mgt, 20, 351-360 (1999)

25. H.C. Choi \& E. Sirakaya. Tourism Mgt, 27, (2006) 1274-1289 (2006)

26. S.F. McCool. National Recreation and Park Association 3-7 (1995)

27. J.C. Nunnally \& I.H. Bernstein. McGraw-Hill. (1994)

28. T.V. Singh. Publishing Company, 30-41 (2003)

29. S.F. McCool. JTR, 40, 2, 124-131 (2001)

30. G. Dann. Contemporary Issues in Tourism Development, Routledge (1999) 13-30 (1999)

31. WWF Tourism (2004)

32. C. Tosun. and D. Timothy. JTS 14, 2, 2-12 (2003)

33. K. Meethan. Palgrave. (2001)

34. R. Sharpley. Tourism, JAPA, 54, 3, 360-372 (1994)

35. T. Winter. JHT 4, 2, 105-115. (2008)

36. C. Aas, A. Ladkin. and Fletcher, J. ATR 32, 1, 28-48 (2005)

37. C. Cooper, J. Fletcher, S. Wanhill, D. Gilbert, and R. Shepherd. Pearson Edu (1998) 